\title{
Kerkverband: 'n Poging tot reformasie in die negentiende eeu
}

\author{
Barry van Wyk (Tsumeb, Namibië) ${ }^{1}$ \\ HervormdeTeologiese Kollege \\ Universiteit van Pretoria
}

\begin{abstract}
Church-denomination: A nineteenth century attempt to reformation

The view exists that the term denomination is especially evident of the nineteenth century Netherlands at the time when an attempt was made to accomplish change in the Nederlandse Hervormde Kerk. The decay in the Church at the time can mainly be ascribed to the influence of the authorities on the church, material welfare, as well as the climate of thought which originated in the Aufklärung. During this period two theologians were prominent, namely $P \quad J$ Hoedemaker and A Kuyper. The latter protested against the synodic structure of the existing Church and proposed an alternative locally free church in its place, consisting of chosen, reborn members of the church who become part of the church by confession. At the time denomination had a prominent function in the integration of all local churches into a single denomination with the confession being the common source of fellowship.
\end{abstract}

\section{INLEIDING}

Die begrip kerkverband bring noodwendig die kerklike debat wat in die negentiende eeu in Nederland aan die orde was ter sprake. Die mening bestaan dat die begrip veral sterk figureer gedurende die tweede afskeiding uit die Nederlandse Hervormde Kerk wat in 1886 sy hoogtepunt bereik en bekend staan as die Doleansie. Aangesien laasgenoemde beweging as ' $n$ reformasie aangedui word (Kuyper 1883; Kuyper \& Rullman 1936) vorm kerkverband een van die uitgangspunte op grond waarvan die aksie geloods word. Ter wille van ruimte word die aandag hoofsaaklik op A Kuyper (18371920) as prominente figuur uit die Doleansie gevestig, waarmee nie geïmpliseer word dat hy die enigste woordvoerder van die Doleansie was nie

\footnotetext{
${ }^{1}$ Lesing gehou voor die Kerkregwerkgemeenskap van Suid-Afrika op Potchefstroom, 6 en 7 September 2005.
} 
(kyk Van Leeuwen 1946:217-270). Die agtergronde van die ontstaan en ontwikkeling van die beweging wat sy hoogtepunt in 1886 bereik, spreek mee en moet in ag geneem word wanneer gepoog word om die betekenis en draagwydte van die begrip enigsins aan die orde te stel.

\section{AGTERGROND EN AANLOOP}

Sedert die bekende Sinode van Dordrecht 1618-19 wat in 'n sekere sin as die eindpunt van die Nederlandse kerkregtelike ontwikkeling beskou kan word, verloop daar bykans twee honderd jaar tot die volgende Sinode met sy besluite soos geformuleer in die Algemeen Reglement van 7 Januarie 1816 wat op 1 April 1816 in werking getree het (Rasker 1981:27). 'n Vergelyking van die twee kerkordes wat uit bogenoemde sinodes volg dui meteen aan dat die Algemeen Reglement 'n radikale verandering verwoord teenoor die Kerkorde wat by die Sinode van Dordrecht in 1618-1619 vasgestel is. Die verandering kon voorspel word as in gedagte gehou word dat die ouer Kerkorde die resultaat was van 'n kerkregtelike debat sedert die Konvent van Wezel 1568, Emden 1571 as die eerste volwaardige Sinode op Nederlandse bodem, gevolg deur die sinodes van 1578, 1581 en 1586 wat as vormende dinkwerk vir die Dordtse Sinode van 1618-1619 en sy Kerkorde gedien het. Dit ten spyte van die patronaatsreg as lastige invloed van die owerheid waardeur die kerk bepaalde toegewings aan die owerheid gemaak het en 'n gedeeltelike onderhorigheid aan die owerheid aanvaar het (Artikels 4, 28, 37 , 50, Kerkorde van Dordt 1618-1619; Kersten 1980:177-194). 'n Verdere leemte was dat die Kerkorde van 1618-19 nie algemeen aanvaar is nie maar slegs deur die provinsies Utrecht, Gelderland en Overijssel ingevoer is, terwyl Holland, Friesland en Zeeland dit nie aanvaar het nie hoofsaaklik vanweë die beperkte seggenskap van die owerheid in kerklike sake. "So het die kerkorde van Dordrecht wat in baie opsigte beskou kan word as die klassieke uitdrukking van die presbiteriaal-sinodale sisteem van kerkregering, soos dit in Nederland in die sestiende en sewentiende eeu ontwikkel het, eintlik nooit werklik tot sy reg gekom het nie" (Pont 1981:171).

$\mathrm{Na} 1619$ kom daar nie weer 'n sinodale vergadering byeen nie. Dit was te wyte aan die owerheid wat sy wurggreep op die kerk nie laat los het nie. "De overheid beschouwde zich niet zonder meer gehouden tot dienstbetoon jegens de kerken, doch was juist van mening dat de kerk zich uitsluitend had te bewegen de door haar te stellen kaders. Daarnaast moet niet vergeten worden dat het houden van een synode een fikse aanslag was op het budget van de Staten" (Post 2003:48). Alhoewel geen verdere nasionale sinode tot en met 1816 byeengekom het nie, het daar tog bepaalde provinsiale sinodes plaasgevind in soverre hulle deur die provinsies toegelaat is (Pont 1981:188; 
1994:123) en het dit effektief beteken dat kerklike besluite veral op klassikale vlak geneem is (Post 2000:48; Nauta 1971:23).

Hoe hardnekkig die owerheid se invloed gegeld het word geïllustreer deur die feit dat die owerheid dit tog sy plig ag om kerklike sake te reël, selfs nadat díé bevoegdheid deur die gewysigde Grondwet die owerheid ontneem is met die motivering: "gedrongen door de nood, en bezield met de begeerte tot zijn welzijn" (Oostenbrink-Evers 2000:28; Roijaards 1834:61).

Die invloed van die owerheid in die kerk was egter nie alleen vir die kerklike impasse verantwoordelik nie. Die kerk word dikwels nie onaangeraak gelaat nie deur die omstandighede waarin hy sy taak moet uitvoer waardeur die wese van die kerk onder druk geplaas word. Die jaar 1651 as die moment van die proklamasie van die vereniging van die sewe Nederlandse provinsies in 'n Gereformeerde Kerkstaat (Haitjema 1964:15) na onafhanklikheid van Spanje met die Unie van Utrecht op 26 Julie 1579 (Heppe 1979:76), lui 'n tydperk van voorspoed in en word as die goue eeu tipeer. "En nu was 'de gouden eeu' in ons vaderland ongetwijfeld een tijd, waarin de toenemende weelde en materiële welvaart die aandacht voor de bedijking van ons gereformeerde volksbestaan deed verslappen" (Haitjema 1964:18; kyk ook Pont 1994:122). Haitjema verwys verder na Groen van Prinsterer wat die situasie soos volg beskryf het: "Regtzinnigheid was bij een groot deel ook der leeraars van kracht en leven beroofd. De leer van genade en zaligheid was hun eene verzameling van wel gerangschikte begrippen, eigendom van het verstand, waaraan het hart geen deel had; dor geraamte, door geen levensgeesten bezield ...".

Haitjema (1964:19) stel naas die voorspoed wat kenmerkend van die tyd was ook die invloed wat die Aufklärung tot gevolg gehad het, en daarin bestaan het dat die mens en sy rede beklemtoon is as die maatstaf vir die waarheid (Pont 1991:79 e v). "In ihm ist die Selbständigkeit des vernünftigen Selbstbewusstseins gegenüber der positiven Religion ausgesprochen. Die Vernunft hat in sich selbst das natürliche Licht (lumen naturale), vermittels dessen sie die umfassende und grundlegende Wahrheit über Gott, Welt, und Mensch finden kann" (Religion in Geschichte und Gegenwart=RGG, 1957:703; kyk ook Popma 1956:373; Pont 1994:149; Le Roux du Plooy 1982:374 e v; Bakhuizen van den Brink, J N et al 1968:78-93). Fiolet (1953:59) wys daarop dat daar in Duitsland 'n verskuiwing plaasvind van die Hegeliaanse idealisme na die natuurwetenskaplike realisme wat daarop neerkom dat die mens na die werklikheid neig waar positiewe feite en onveranderlike wette geld wat met natuurwetenskaplike metodes verkry is en nie deur die spekulatiewe menslike gees nie. Die neiging vind ook in Nederland sy vastrapplek in die denke van René Descartes (1596-1650), 
Baruch Spinoza (1632-1677) en Pierre Bayle (1647-1706). Die verligte denke lei daartoe dat die kerk nie meer gesien en waardeer word soos aangedui in Artikel 27 van die Nederlandse Geloofsbelydenis nie. Die kerk word veel eerder beskou as 'n landelike vereniging wat godsdiens beoefen ter verbreiding van die denke wat deur die Verligting geïmpliseer word. Geloof word die aanname van die deur die rede getoetste en as waar geykte, leer en voorskrifte van Jesus (Vree 1984:42).

Kerklike denke word dus nie met rus gelaat nie maar ondergaan dikwels ook die invloed wat uit die omliggende geestesstrominge aan die orde is. Geloof as 'n menslike bewys in die bestaan van God wat objektief van aard is, word onder druk geplaas deur die menslike rede wat na subjektiewe bewysvoering vra. Op díe wyse word die Bybel 'n vindplaas vir bewysvoering en sodoende vervlak tot 'n hulpmiddel vir menslike redevoering.

Op die geestesklimaat van die dag word gereageer deur die Gereformeerde Ortodoksie waarvan die Sinode van Dordt 1618-19 'n voorbeeld was en sedert die Konsilie van Trente in 1563 deur iemand soos Beza (1519-1605) voortgesit word, maar met gebruikmaking van die Skolastieke teologie wat gebaseer was op die logika van Aristoteles as antwoord en reaksie teen die Rooms-Katolieke aanslag (Pont 1994:125). Graafland dui aan dat Beza die leer van die uitverkiesing aan die begin van sy geloofsleer plaas wat 'n "causale ordo salutis zich ontwikkelt, waarin de heilsmomenten in de realisering van de verkiezing logisch op elkaar volgen" (Graafland 1987:67). Dit beteken dat nie noodwendig die geloof nie maar die wedergeboorte kenteken word van die feit dat iemand uitverkore is. Wedergeboorte word die subjektiewe menslike kant van die verkiesing en sodoende word heilsekerheid in die menslike belewing en uitlewing gesoek. Sodoende het die klem verskuif van die regverdiging van die sondaar na die innerlike heiliging van die wedergeborene. Dit was juis die klem wat deur die Nadere Reformasie gelê is. "So word die Gereformeerde Ortodoksie, juis vanweë die aksentverskuiwing wat dit met hom saamdra, 'n stimulans vir die subjektiewe Nadere Reformasie en vir 'n geleidelike agterstel van die Gereformeerde teologie in die Nederlandse kerklike wêreld" (Pont 1994:26).

Graafland wys daarop dat Beza, maar ook andere soos Z Ursinus, L Danaeus en $\mathrm{H}$ Zanchius leef en werk in die tweede helfte van die sestiende eeu, dus in die jare sestig tot tagtig as die periode wat direk op Calvyn gevolg het. Hy wys daarop dat hulle van Calvyn afstand neem en oorgaan "naar een sterk gesystematiseerde en afgeronde gereformeerde rechtzinnigheid, die daarin met de wisseling van de 16 de naar de 17 de eeuw, tot een min of meer volwasse gestalte is gekomen" (Graafland 1987b:6). Met verwysing na Bizer wys hy daarop dat daar 'n ontwikkeling plaasvind van die vroeë ortodoksie 
van Beza en andere, na die daaropvolgende volgroeide ortodoksie, maar dat beide weer 'n skakel gevorm het met die opkomende Rationalisme wat in die teologie van die Verligting sy rypwording beleef. "Zo is er dus een ontwikkeling geconstateerd, die met de Gereformeerde Reformatie is ingezet, en via Frühortodoxie en Hochortodoxie tenslotte is uitgemond in de Verlichting" (Graafland 1987b:6).

Dit het tot gevolg gehad dat die leer van die kerk op die voorgrond geplaas is en dat die Bybel gereduseer is tot die vindplaas vir bewysvoering van die leersisteem. "Dit bring mee dat die geloof uitgehol en vervlak word tot 'n formele, verstandelike aanvaarding van die dogmatiese sisteem" (Pont 1994:122; kyk ook Berkhof \& De Jong 1967:209).

Post (2003:49; kyk ook Le Roux du Plooy 1982:365 e v) wys daarop dat iemand soos Gisbertus Voetius (1589-1676), "als voorvechter van de gereformeerde orthodoxie", ook 'n belangrike bydrae op kerkregtelike gebied gelewer het deur sy nadere verklaring van die presbiteriale beginsels soos vervat in die Dordtse Kerkorde van 1618-1619. Hy hou hom besig met die suiwerheid van die leer wat opnuut deur die Sinode vasgestel is, asook met die feit dat kerklike regsreëls op die Skrif gefundeer moet wees. Hy gee aandag aan die verhouding tussen die plaaslike kerk en die kerkverband. Pont (1994:128) noem dat die oorheersende indruk wat Voetius maak die is van 'n polemikus. Na Dordrecht (1618-1619) word hy die groot woordvoerder van die Ortodoksie (kyk ook Graafland 1987; Heppe 1979:144-154). As verbete aanhanger van Aristoteles se filosofie stel hy hom teen die van Descartes. Sy primêre belangstelling setel egter in die "praktijk der godzaligheid".

As dit gestel word, is dit belangrik om daarop te let dat by Voetius die ware, regte leer die voorwaarde is vir "die Godsalige lewe", dit is 'n vroom lewe toegewy aan en gehoorsaam aan die Woord van God. Die ware, regte leer is nooit sonder meer gerig op die intellek nie, maar eerder op 'n lewe van gehoorsaamheid en vroomheid. Daarom kan die ware leer nooit ' $n$ doel in homself wees nie, maar is dit die voedingsbodem vir die ware lewenstyl. (Pont 1994:128; kyk ook Van 't Spijker 1989:242-256)

Voetius was nie in staat om die reaksie teen die formalistiese dogmatisme van die Calvinistiese Ortodoksie te keer nie. Reaksie kom van Coccejus wat die dogmatiese sisteem met 'n nuwe Bybelse teologie wil aftakel; Descartes wat die sisteem met 'n menslike rasionalisme wil hersien en die Nadere Reformasie en Peïtisme wat wedergeboorte en heiligmaking beklemtoon as teenvoeter vir die dogmatiese sisteem. 
Nadere beskouing van die Algemeen Reglement van 1816 dui verder aan dat dit 'n meganisme is wat aan die kerk gegee is waardeur die kerk bestuur kon word. Dit word sodanig ook in die Algemeen Reglement van 1816 aangedui (Hooijer 1846:25; Oostenbrink-Evers 2000:29; Post 2003:70; Pont 1991:87). Daarmee was dit duidelik dat die onderlinge verhouding tussen die Skrif, belydenis en die kerklike orde losgelaat is. Die loslating van die relasie het veral geblyk uit die feit dat die owerheid in gebreke gebly het om hom uit te spreek oor aangeleenthede wat die belydenis raak.

\begin{abstract}
Men eiste van haar handhaving van de leer. Natuurlijk, de drie Formulieren van Enigheid bleven immers van kracht. Doch tegelijkertijd verklaarde zij zich onbevoegd door een uitspraak duidelijk te omschrijven, wat precies tot de leer behoorde .... Dit waren de wapenen - zich onbevoegd verklaren tot iedere leeruitspraak en onbewogen blijven onder iedere kritiek -,..."
\end{abstract}

(Fiolet 1953:31)

In verband met die handhawing van die leer van die kerk het die proponentsformule van die Algemeen Reglement deur sy vaagheid daartoe gelei dat die binding aan die leer van die Kerk na 1854 uiteindelik volledig op die quatenus uitgangspunt beland het wat ' $n$ sterk vlaag van kerklike protes tot gevolg gehad het (Pont 1991:99; Nauta:1969; Fiolet 1953).

\title{
3. AFSKEIDING OF REORGANISASIE: KUYPER EN HOEDEMAKER
}

Die sterkste vorme van protes ontstaan in die Afskeiding van 1834 waar Hendrik de Cock (1801-1842) prominent figureer het (kyk Van 't Spijker 1985; Bakker et al 1984), asook deur die Doleansie in 1886 wat sinoniem is met die naam van Abraham Kuyper. Wanneer die name genoem word kan dit nie anders nie dat die naam van P J Hoedemaker (1839-1910) ook bygevoeg word as een van die belangrike woordvoerders uit die gedeelte van die Kerk wat nie met die Doleansie saam gegaan het nie. Die volgende uitspraak van Hoedemaker verwoord iets van die verskil in siening in die denke van Kuyper en Hoedemaker met betrekking tot hulle onderlinge verstaan van die kerk, en derhalwe hoe die kerklike stryd bygelê moet word:

Hoedemaker keurde de doleantie scherp af, omdat men langs die weg alleen zichzelf van de besturen bevrijdde, en niet de kerk. Hij vergeleek de kerk met een man die onder een balk vandaan gehaald moest worden. "lemand ligt onder een zware balk ... hoe komt hij er onder uit? Bij stukken en brokken?...Laat hem dan nog een poosje liggen. Want het leven is er niet mee gemoeid." Die balk 
was de organisatie van 1816. Maar men mocht van deze man daaronder, wilde men zijn leven ontzien, niets amputeren.

(Balke 1992:99)

Daar was één gemeenskaplike noemer wat by alle partye terug gevind word met betrekking tot die kerklike situasie waarin die Kerk in die negentiende eeu verkeer het, en dit was dat die situasie wat veral na 1816 ontstaan het, nie kon voortduur nie. Die vraag wat ter sprake gekom het was egter hoe die "sware balk" wat op die kerk gerus het verwyder moes word. Hoedemaker gee die volgende mening oor die toestand waarin die Kerk verkeer het:

De organisatie verloochent het Presbyteriaal karakter van de Kerk, verkort de rechten der opzieners, beperkt het rechtsgebied der kerkeraden, bespot de representatie der Kerk in de klassen, verzaakt het beginsel, dat Christus het eenige Hoofd, dat Zijn Woord het eenige richtsnoer is van die Kerk, oefent onder Gereformeerde benamingen eene bisschoppelijke macht uit, maakt de belijdenis tot een petrefact, waarvan geen bezielende, oordeelende en vereenigende kracht in dien vorm kan uitgaan en onderdrukt daarmede het eigenlijke leven der Kerk.

(De Heraut, 1880, 130, in Scheers 1939:197)

Die vraag kan gevra word waarom die reaksie teen die kerklike verwording nie groter en meer fel was nie. Die lastige invloed van die owerheid in kerklike aangeleenthede en die tydgees wat deur die Verligting oor Europa vaardig was, is reeds genoem as moontlike oorsake waarom dit so lank geneem het om tot kerklike herstel te kom. Vree (1984:41) voeg daarby óók dat die owerheid na die Franse tyd weer die traktemente van die predikante betaal het waardeur armoede in pastorieë weer herstel is, asook die behoefte na rus en vrede wat onder die volk geheers het (Fiolet 1953:13).

Die wesenlike van die debat tussen die twee genoemdes kan waarskynlik saamgevat word in die feit dat hulle oor die kerk as sodanig met mekaar verskil het. Wanneer die debat nagelees word kom die siening enersyds van die kerk as volkskerk en andersyds die kerk as vryekerk telkens ter sprake. Dat Kuyper nie 'n aanhanger van die kerk as volkskerk was nie blyk onder andere uit 'n uitspraak soos die volgende:"hef de eene massale kerk op, laat dien gedrochtelijke kolossus, door eigen topswaarte kantelen, vergruizelen in zijn deelen" (aangehaal by Van Deelen 1934:8; kyk ook Kuyper 1883:52). 'n Verdere uitspraak beklemtoon ook díe siening: 'n volkskerk is "tegen de analogie des geloofs en weerspreekt de grote 
tegenstelling tussen Christus en de wereld, die van Genesis drie tot Openbaring negentien de hoofdgedachte der Schrift vormt" (Kuyper 1873:83; kyk ook Spoelstra 1986:98).

Enkele biografiese gegewens uit die lewe van Kuyper dui aan dat hy veral deur die lees van die roman The Heir of Redcliffe, sy aanraking in die gemeente Beesd met 'n groep gelowiges wat uit die gees van die Nadere Reformasie geleef het, en sy ervaring van die Brighton-revivals geïnspireer word tot verdere studie. Hy lees die geskrifte van De la Saussaye, Gunning, Calvyn en andere. Kuyper is waarskynlik ook deur Alexander Vinet (17971847) beïnvloed wat 'n voorstander van die vryekerk was. "Hij ziet ze niet als een instelling sui generis, maar als een gewone menslijke vereniging, die door de vrijwillige toetreding der leden gevormd wordt" (Langman 1950:14, 162).

So word herstel van die kerk tot ware moeder van die gelowiges sy lewensdoel (Rasker 1981:172; Pont 1987:508; Haitjema 1964:243; Langman 1950:161vv; Van Deelen 1936:246). Uit sy proefskrif waarin hy die kerkbegrippe van Calvyn en á Lasco met mekaar vergelyk blyk 'n voorkeur vir laasgenoemde wat die kerk primêr omskryf as 'n societas fraterna Dei liberorum (Pont 1987:508; Van Deelen 1936:241). Langman wys daarop dat die invloed van die Groninger rigting in die tyd nie onderskat moet word nie en waarskynlik daartoe lei dat Kuyper 'n voorkeur openbaar vir á Lasco (Langman 1950:161). Dit was dus vanselfsprekend dat Kuyper na 'n kerk gesoek het wat hy in die Kerk van sy tyd nie teruggevind het nie.

Na aanleiding van Efesiërs 3:17 onderskei Rasker (1981:175) die kerk as organisme en as instituut (kyk ook Spoelstra 1986:102):

De kerk alleen als organisme gedacht, zou gevaar lopen in de samenleving te vervluchtigen, alleen als instituut, zou zij in gevaar zijn van verstening; beide aspecten horen echter bijeen in de vrije kerk: zij is organisme door het nieuwe leven, de Geest in haar uitgestort, zij is instituut als een stichting waarin ordening moet zijn; als organisme is zij onze moeder, als instituut onze opvoedster.

Hieroor maak Oostenbrink-Evers (2000:37) die volgende opmerking: "In Kuypers theologie staat het organisme op de eerste plaats, maar in de praktijk van het kerkelijk leven daarentegen is de kerkvorm of het instituut van de grootste betekenis geweest. Kenmerkend is dat het kerkelijke vraagstuk, dat Kuypers volle aandacht had, niet betrekking had op het organisme, maar op het instituut."

Die kerklike debat van die negentiende eeu in Nederland vind plaas teen 'n bepaalde agtergrond en word gevoer binne 'n gegewe konteks. Kuyper as die hoofwoordvoerder van die Doleansie (Pont 1987:508; Van den 
Berg 1986:76) was kind van sy tyd en reageer teen 'n bepaalde bestel waarvoor inderdaad begrip was, maar waaroor nie noodwendig eenstemmigheid bestaan oor die manier waarop die probleem opgelos moes word nie.

Kuyper se antwoord om die kerklike situasie te verbeter en die impasse te verlig waarin die Kerk van die negentiende eeu, en veral na 1816 verkeer het, was om die bestaande kerk te verlaat. Die alternatief was nie nuut nie aangesien dit ook die uitweg was wat Hendrik de Cock in 1834 gevolg het. Behalwe afskeiding en die stigting van 'n ander kerk as gevolg van die verworde toestand waarin die bestaande Kerk hom bevind het, kom hier ook 'n ander kerkbegrip ter sprake wat as vryekerk tipeer is. Die swaar klem op die vryheid in díe kerkverband gee die moontlikheid om van die bestaande af te skei met die argument dat die plaaslike gemeente altyd in die eerste plek die kerk is (Kuyper 1874:26). Dit beteken dat afskeiding van die sinodale verband van die bestaande Kerk voor die hand liggend word. " $[\mathrm{H}] \mathrm{ij}$ zelf is toch zonder twijfel in het andere uiterste vervallen, nl. in de overschatting van de plaatselijke kerken, die volgens hem niet alleen volledige maar ook in wezen autonome kerken waren" (Haitjema 1936:264).

Pont (1987:511) wys daarop dat die vrye kerkgedagte deur Kuyper as 'n vanselfsprekendheid in die gereformeerde kerkreg ingedra is en hy vind daarvoor nie net aansluiting by Gijsbertus Voetuis, die $17^{\mathrm{e}}$ eeuse canonicus nie (Polit Eccl: I, 61-65; kyk ook Van 't Spijker 1989:255-6; Kromsigt 1933:90), maar ook by À Lasco en ander Puriteinse independente (kyk ook Van Leeuwen 1946:257; Van Deelen 1934:7). In Separatie en Doleantie waarin die invloed van Voetius blyk stel Kuyper onder andere die volgende: "Van geen mensch laten ze zich een kerk door dwang opleggen, en met geen mensch treden ze anders dan uit vrije overtuiging in kerkelijke gemeenschap" (Kuyper 1890:10). Die profiel van die lidmaat wat sodoende vrywillig tot die kerk toetree is die van die uitverkore, wedergebore lidmaat wat op grond van sy belydenis tot die kerk toetree. "Immers voor de eerste openbaring van het wezen der kerk is zeer zeker een kring noodig van uitverkorenen, die tevens reeds volwassen en besliste belijders zijn" (Kuyper 1883:31). Langman (1950:165; kyk ook Haitjema 1964:247-248) beskryf dit as 'n "sterk geaccentueerde predestinatie-leer, die we bij Kuyper vinden, met als correlaat daarvan de leer van de wedergeboorte, en in verband daarmee de zwakheid van zijn verbondsleer." Dit loop ook daarop uit dat Woord en Sakrament geen wesenlik, konstituerende elemente van sy kerkbegrip uitmaak nie omdat die wesenlike van die kerk bestaan in die gemeenskap van die gelowiges wat in verband met die uitverkiesing gebring word (Kuyper 1883:48; Van Deelen 1936:244). Die sterk klem op die uitverkiesing as uitgangspunt van sy 
ekklesiologie verskuif ook die klem van die Goddelike verkiesing na die uitverkore lidmaat met as korrelaat die wonder van die wedergeboorte en die wedergebore lidmaat.

Kuyper se kerkbegrip werk met 'n vrye outonome gemeente wat as plaaslike kerk volledig kerk is, en sodoende die hoeksteen van sy kerkregtelike stelsel vorm (Kuyper 1883:36, 48; kyk ook Langman 1950:97; Haitjema 1964:244). "Uitgaande van autonomie der plaatselijke gemeente zocht hij naar een confederatief verband op basis van de klassieke gereformeerde belijdenisgeschriften als accoord van kerkelijke gemeenschap" (Nijenhuis 1986:188).

Uit die ekklesiologie van Kuyper tree dus die kerkverband na vore wat die vrye en outonome "kerke" weer moet saamsnoer in 'n konfederatiewe kerkverband, geskoei op die belydenis as akkoord van gemeenskap as korreksie van die landelike kerk in organiese verband. "De belijdenis en niet de kracht van het verbond vormt het cement, dat de leden en de deelen der Kerk met elkaar vereenigt. De belijdenis dreigt verward te worden met kerkelijke eenheidswet" (Van Deelen 1936:250). Kuyper stel dat die kerkverband uit die plaaslike kerke te voorskyn kom en gebruik die woord ekklésia as aanduiding van die enkele kerk, en die meervoud wanneer meer kerke ter sprake is. Hy meen verder dat daar nêrens enige aanduiding gevind word "dat zij de opsmelting van de plaatselijke kerken in zekere nationale eenheid als voorwaarde voor het behoud en het wezen eener kerk stellen." Hy sluit die gedeelte met die volgende slotsin: "En kan dit heur niet betwist, zoo staat het dan ook vast, dat de kerkeenheid, waarvan we hebben uit te gaan, niet in wereldkerk, noch ook in landskerk of classen, maar uitsluitend in de locale kerk gegeven is" (Kuyper 1883:35-36 e v; kyk ook Kromsigt 1933:98). 'n Kerk op 'n bepaalde plek wat homself as openbaring van die liggaam van Christus beskou, moet met ander soortgelyke kerke in korrespondensie tree. "Eenheid van belijdenis is de onmisbare grondslag, waarop alle kerkelijke korrespondentie, en dus ook alle kerkverband, moet staan". Die kerkverband wat so ontstaan het verskillende pligte waarvan die handhawing van die Formuliere van Eenheid as eerste doel beskou is (Kuyper 1883:77, 78). Dit is juis die funksie van die geloof waardeur gelowiges "in onderling verband treden, zich aaneen sluiten, een kerk in het zichtbare formeeren en om hun formatie een kerk te doen zijn, die formeeren in persoonlijke en gemeenschappelijke gehoorzaamheid aan het Woord van God" (Kuyper 1883 27).

Kuyper reageer teen die verwording van die destydse Nederlandse Hervormde Kerk as volkskerk, deur die weg van separatisme te volg en sy uittrede te motiveer aan die hand van 'n kerkbegrip wat kenmerkend van die 
vryekerk is. Aangesien hy sodoende uit die bestaande kerk uittree en die sinodale struktuur wil breek wend hy hom tot die plaaslike gemeente as ecclesia completa wat bestaan uit uitverkore, wedergebore lidmate wat vrywillig toetree tot die plaaslike kerk op grond van die belydenis as akkoord van gemeenskap. Die swaar klem op die vrywilligheidseginsel verraai iets van 'n independentisme en staan in kontras met die Nederlandse Geloofsbelydenis wat in Artikel 28 aandui dat almal verplig is om hulle by die kerk aan te sluit omdat buite die kerk geen saligheid is nie (Kromsigt 1933:90). As antwoord op die sinodale struktuur stel hy die kerkverband as alternatief, as 'n kerklike struktuur wat die plaaslike kerke weer moet saamsnoer, maar op die basis van vrywilligheid. Laasgenoemde vorm die agterdeur waarlangs uit die kerkverband getree kan word indien 'n plaaslike kerk nie met die verloop van sake instem nie. Kerkverband as sodanig, asook sy volledige kerkbegrip is die grondtrekke waarop Kuyper die Doleansie wat op 'n tweede afskeiding uitloop, deurgevoer het. Oostenbrink-Evers (2000:38) vat dit soos volg saam:

\begin{abstract}
Kuypers stelsel gaat er daarentegen van uit dat elke locale kerk in zichzelf het wezen van een kerk bezit en dat het uiterlijk verband in rechten met andere kerken niet anders dan door "confederatie" tot stand komt. Dus net zoals de plaatselijke kerk tot stand komt door vrije aaneensluiting van de gelovigen, zo komt het kerkverband tot stand door vrije aaneensluiting van plaatselijke kerken. Het organische geheel wordt dus alleen gevormd door de onzichtbare kerk. Het wezen van het instituut is in de plaatselijke kerk gegeven en het kerverband kan alleen het welwezen aan het wezen toevoegen.
\end{abstract}

Wanneer Kuyper en Hoedemaker, die twee prominente woordvoerders van díé tyd met mekaar vergelyk word, is dit duidelik dat hulle benadering téénoor mekaar gestaan het. In Hoedemaker se bekende geskrif, Heel de kerk en heel de volk, dui hy aan dat die geneesmiddel vir die krankheid van die kerk is om "niemand zoeken te verdringen of te verdrijven, maar eenvoudig terug gaan naar het begin van de weg, waarvan het einde zal zijn: de belijdende kerk, die, als uitdrukking van hare eenheid, hare belijdenis heeft, maar die belijdenis onderzocht, gehandhaafd, vernieuwd, ..." (Hoedemaker 1897:33). Van Wyk (1999:139) stel dit soos volg:

Die reformasie van die kerk moet nie net vir diegene ten goede kom wat reeds tot die waarheid gekom het nie, maar vir almal wat in die verbond van God inbegrepe is. Daarmee het Hoedemaker lynreg teenoor Kuyper te staan gekom, vir wie die kern van sy kerkbegrip in die weergeboorte gesetel het. Vir Kuyper is die kerk daar waar 
Kerkverband: 'n Poging tot reformasie in die negentiende eeu

die ware belyers is; vir Hoedemaker daar waar Woord en sakrament bedien word.

'n Ander figuur in díé tyd wat nie met die Doleansie saamgegaan het nie was H F Kohlbrugge (1803-1875) wie se standpunt soos volg deur Loos (1948:180) weergegee word:

Tegenover de peïtistiese meening, dat de wedergeboren mensch soortelijk verschilt van de onwedergeborene, stelde Kohlbrugge de prediking, dat de wedergeborene vleesch is. Tegenover de peïtistische neiging om de wedergeborenen samen te brengen in een conventikel, een afgescheiden gemeente, en "vrije" kerk, stelde Kohlbrugge de solidariteit van al wat mensch is, van al wat sondaar is. Tegenover de "iustificatio electi" der separatisten, wier credo immers een zeer bepaald getinte leer der praedestinatie is, stelde hij de "iustificatio impii" Tegenover de separatistische antithese tusschen geloovigen en ongeloovigen stelde hij scherp die andere antithese, de tegenstelling tusschen God en mensch, tusschen Geest en vleesch.

\section{SLOTOPMERKINGS}

Uit bogenoemde standpunte blyk dat kerkverband in die verlenging lê van kerkbegrip wat die uitgangspunt vir die Doleansie van 1886 vorm. Die gebeure word egter nie oral op dieselfde manier beoordeel nie. Vyftig jaar later stel Dijk (1936:326) onder andere die volgende mening:

Zij heeft niet eigen nieuwe ideeën gepropageerd en voor een eigen, niet eerder verdedigd, principe den strijd gevoerd, doch zij is, evenals ook de Afscheiding, eenvoudig teruggegaan tot het Woord Gods en tot de Belijdenis der vaderen, om weer in gehoorzaamheid aan dat Woord en in getrouwheid aan de belijdenis op het erf van des Heeren Kerk te leven.

Die feit dat die Doleansie as reformasie beskou is word uit Hervormde kringe nie goed beleef nie, en word onder andere die kritiese vraag gevra na die verband tussen 1886 en 1517 (Miskotte 1971:61).

Ten slotte word hier gemeld dat die Nederlandse Hervormde Kerk, die Gereformeerde Kerken in Nederland en die Evangelisch-Lutherse Kerk sedert 1 Mei 2004, één Kerk vorm bekend as die Protestantse Kerk Nederland (Van den Heuvel 2004:13). Behalwe dat die Kerkorde van díé Kerk sterk ooreenkomste vertoon met die voorafgaande Kerkorde van die Nederlandse Hervormde Kerk, word onder andere in Artikel II gemeld dat "De Protestantse Kerk in Nederland bestaat uit al de gemeenten, te weten de protestantse 
gemeenten, de hervormde gemeenten, de gereformeerde kerken en de evangelisch-lutherse gemeenten" (Kerkorde en ordinanties van de Protestantse Kerk in Nederland inclusief de overgangsbepalingen=PKN 2004: 10).

In die lig hiervan moet bepaalde verskille met betrekking tot kerkbegrip wat moontlik in die verloop aan die lig gekom het met geduld bejeën word gesien teen die ommeswaai wat in Nederland sedert 1886 tot 2004 plaasgevind het.

\section{Literatuurverwysings}

Bakhuizen van den Brink, J N et al 1968. Handboek der Kerkgeschiedenis, vierde deel, $3^{\mathrm{e}}$ druk. Den Haag: Bakker/Daamen.

Bakker, W et al (red) 1984. De Afscheiding van 1834 en haar geschiedenis. Kampen: Kok.

Balke, W 1992. Heel het Woord en heel het Kerk. Kampen: De Groot Goudriaan.

Berkhof, H \& De Jong, O J 1967. Geschiedenis der kerk, zevende druk. Nijkerk: Callenbach.

Dijk, K 1936. Het kerkbegrip der Doleantie, in Kuyper, H H \& Rullmann, J C (red), De Reformatie van 1986: Gedenkboek bij het halve-eeuwgetij der Doleantie, 321347. Kampen: Kok.

Fiolet, A 1953. Een kerk in onrust om haar belijdenis. Nijkerk: Callenbach.

Graafland, C 1987. Van Calvijn tot Barth. 's-Gravenhage: Boekencentrum.

Graafland, C 1987b. Gereformeerde Scholastiek, V: De invloed van de Scholastiek op de Gereformeerde Orthodoxie. Theologia Reformata XXX, 1, 4-25.

Haitjema, Th L 1936. De Doleantie en ons kerkelijk vraagstuk: Onder eigen vaandel, elfde jaargang.

Haitjema, Th L 1964. De nieuwere geschiedenis van Neerlands Kerk der Hervorming. 's-Gravenhage: Boekencentrum.

Heppe, H 1979. Geschichte des Pietismus und der Mystik in der Reformirten Kirche, namentlich der Niederlande, reprografischer nachdruck. Goudriaan: De Groot.

Hoedemaker, P J 1897. Heel de kerk en heel het volk. Kampen: Sneek.

Hooijer, C 1846. Kerkelijke wetten voor de Hervormden in het Koningrijk der Nederlanden. Zalt-Bommel: Noman en Zoon.

Kersten, G H 1980. Kerkelijk handboekje. Utrecht: De Banier.

Kromsigt, P J 1933. Het wezen der kerk, in Oorthuys, G \& Kromsigt, P J, Grondslag en wezen der kerk, 82-135. Wageningen: Veenman \& Zonen.

Kuyper, A 1873. Confidentie. Amsterdam: Höveker \& Zoon.

Kuyper, A 1874. Het Calvinisme oorsprong en waarborg onzer constitutioneele vrijheden. Amsterdam: Van der Land.

Kuyper, A 1883. Tractaat van de Reformatie der Kerken. Amsterdam: Höveker \& Zoon.

Kuyper A 1890. Separatie en Doleantie. Amsterdam: Wormser.

Kuyper, H H \& Rullmann, J C 1936 (red). De Reformatie van '86. Gedenkboek bij het halve-eeuwgetij der Doleantie. Kampen: Kok. 
Langman, H J 1950. Kuyper en de volkskerk. Kampen: Kok

Le Roux Du Plooy, A 1982. Kerkverband. 'n Gereformeerd-Kerkregtelike studie. ThDproefskrif, Universiteit van Potchefstroom vir Christelike Hoër Onderwys.

Loos, J 1948. De theologie van Kohlbrugge. Amsterdam: Holland.

Miskotte, K H 1971. Om de waarheid te zeggen. Kampen: Kok.

Nauta, D 1969. De verbindende kracht van de belijdenisschriften. Kampen: Kok.

Nauta, D 1971. Verklaring van de Kerkorde van de Gereformeerde Kerken in Nederland. Kampen: Kok.

Nijenhuis, W 1986. De Nederlandse Hervormde Kerk en de Doleantie, in Bakker, W et al (red), De Doleantie van 1886 en haar geschiedenis, 178-202. Kampen: Kok.

Oostenbrink-Evers, H 2000. Beginselen en achtergrond van de Kerkorde van 1951 van de Nederlandse Hervormde Kerk. Zoetermeer: Boekencentrum.

Pont, A D 1981. Die historiese agtergronde van ons kerklike reg, Deel 1. Pretoria: HAUM.

Pont, A D 1987. Die betekenis van Abraham Kuyper (1837-1920) vir Suid-Afrika op kerkhistoriese en kerkregtelike gebied. HTS 43(3), 506-521.

Pont, A D 1991. Die historiese agtergronde van ons kerklike reg, Deel 2. Pretoria: Kital.

Pont, A D 1994. Algemene Kerkgeskiedenis: 'n Inleiding tot die Nederlandse Kerkgeskiedenis: van die beginjare tot 1795. Pretoria: Universiteit van Pretoria. (HTS Suppl 6.)

Popma, S J 1956. Aufklärung, in Grosheide, F W \& Van Itterzon, G P (red), Christelijke Encyclopedie, Deel 1, 373-375. Kampen: Kok.

Post, J J H 2003. Een sikkel in een vreemde oogst?: De juridische verhouding tussen hervormde gemeenten en de Nederlandse Hervormde Kerk in het bijzonder bij kerkfusie. Heerenveen: Groen.

Protestantse Kerk Nederland. Generale Synode van de Protestantse Kerk in Nederland 2003. Kerkorde van die Protestantse Kerk Nederland, $2^{\mathrm{e}}$ druk 2004.

Rasker, A J 1981. De Nederlandse Hervormde Kerk vanaf 1795. Haar geschiedenis en theologie in de negentiende en twintigste eeuw. Kampen: Kok.

Religion in Geschichte und Gegenwart=RGG, 1957, Erster Band, A-C, Tübingen: Mohr.

Roijaards, H J 1834. Hedendaagsch Kerkregt bij de Hervormden in Nederland, eerste deel. Utrecht: Altheer.

Scheers, G P 1939. Philippus Jacobus Hoedemaker. Wageningen: Veenman \& Zonen.

Spoelstra, B 1986. Het ons kerkwees in strukture gestol? HTS 42(1), 94-109.

Van Deelen, H C J 1934. Volkskerk, belijdeniskerk, vrijekerk: Naar het herstel der Kerk. Derde serie, nummer 1. Wageningen: Veenman \& Zonen.

Van Deelen, H C J 1936. De theologische achtergrond van de Doleantie: Onder eigen vaandel, elfde jaargang.

Van den Berg, C H W 1986. De ontstaansgeschiedenis van de Doleantie te Amsterdam, in Bakker, W et al (reds), De Doleantie van 1886 en haar geschiedenis, 76-105. Kampen: Kok.

Van den Heuvel, P (red) 2004. De toelichting op de kerkorde van de Protestantse Kerk in Nederland. Zoetermeer: Boekencentrum. 
Van Leeuwen, P A 1946. Het kerkbegrip in de theologie van Abraham Kuyper.

Franeker: Wefer.

Van 't Spijker, W 1985. De kerk bij Hendrik de Cock. (Apeldoornse Studies 21.) Kampen: Kok.

Van 't Spijker, W 1989. Voetius practicus, in Van Oordt, J et al (reds), De onbekende Voetius, 242-256. Kampen: Kok.

Van Wyk, D J C (snr) 1999. Die ander opsie: Kohlbrugge - Hoedemaker - Barth. HTS 55(1), 120-151.

Vree, J 1984. De Nederlandse Hervormde Kerk in de jaren voor de Afscheiding, in Bakker, W et al (red). De Afscheiding van 1834 en haar geschiedenis, 30-61. Kampen: Kok. 